\title{
The Development of Fintech in Indonesia
}

\author{
Teti Anggita Safitri ${ }^{*}$ \\ ${ }^{1}$ Universitas Aisyiyah Yogyakarta, Yogyakarta, Indonesia \\ *Corresponding author. Email: tetianggita@unisayogya.ac.id
}

\begin{abstract}
This study aims to determine the development of financial technology (Fintech) in Indonesia. The research method used is descriptive analysis using quantitative. The data collected is secondary data by the Financial Services Authority (OJK) fintech data. The results showed that there was a high development of financial technology in Indonesia for 18 months (January 2018 - August 2019). The development of fintech in Indonesia shows the progress of financial technology innovation in Indonesia which is very helpful to the community, while the public's interest to use fintech is large given the high number of borrowers over the past year. The community is so familiar with the benefits and use of fintech because the use of fintech is more efficient and effective compared to other financial services so that people are motivated to use fintech.

Keywords: fintech, innovation, crowdfunding, micro, small and medium enterprises
\end{abstract}

\section{INTRODUCTION}

In the Industrial Revolution Era 4.0 at this time, technology has become very important where technology is a tool to facilitate people in optimizing their resources efficiently and effectively. One technology that is very popular with the public is the use of the internet. Based on the results of an Indonesian Poll study in collaboration with the Association of Indonesian Internet Service Providers (APJII), the number of internet users in Indonesia grew by 10.12 percent. According to the Secretary General of APJII, Henri Kasyfi, this field data was taken during the period from March to April 14, 2019, from a total population of 264 million people in Indonesia, there were 171.17 million people or around 64.8 percent who had been connected to the internet. This figure increased from 2017 when the internet penetration rate in Indonesia was 54.86 percent [1]. With the rapid development of the internet fostering innovation in various technology-based industries, one of them is in the financial sector, namely fintech (Financial technology) which is a technology to support financial services. The development of fintech gave rise to various application innovations in financial services, including payment instruments, loan tools, deposit devices and so forth. The transition of people to fintech is based on the ease and speed in accessing various interests, this is what causes fintech to flourish in Indonesia. The objectives to be achieved in this study is to determine the development of fintech in Indonesia and to find out the role of fintech in the development of MSMEs in Indonesia.

\section{LITERATURE REVIEW}

\subsection{Financial Technology (Fintech)}

According to Bank Indonesia, Financial Technology or Fintech is a combination of financial services and technology that eventually changes the business model from conventional to moderate, which initially had to pay for face-to-face meetings and bring some cash, now can make long-distance transactions by making payments that are can be done in seconds.

Fintech emerged in line with changes in people's lifestyles which are currently dominated by users of information technology that demands fast-paced life. With Fintech, problems in buying and selling transactions and payments such as not having time to look for goods to a shopping place, to a bank / ATM to transfer funds, reluctance to visit a place because of the unpleasant service can be minimized. In other words, Fintech helps sales transactions and payment systems become more efficient and economical but still effective.

The legal basis for organizing FinTech in the payment system in Indonesia is 1). Bank Indonesia Regulation No. 18/40 / PBI / 2016 concerning the Implementation of Payment Transaction Processing; 2). Bank Indonesia Circular No. 18/22 / DKSP regarding the Implementation of Digital Financial Services; and 3). Bank Indonesia Regulation No. 18/17 / PBI / 2016 concerning Electronic Money

The benefits of Fintech are A). For consumers, FinTech provides benefits including getting better service and lower prices. B). For FinTech players (merchants of products or services), FinTech provides benefits namely simplifying the transaction chain, reducing operational costs and capital costs and freezing the flow of information; C). For a country, FinTech provides the benefits of encouraging the transmission of economic policies, increasing the velocity of money so that it improves the economy of the people and in Indonesia, Fintech also encourages the National Financial Inclusion Strategy / SKNI.

The impact of Fintech in Indonesia has changed the payment system in the community and has helped start-up companies reduce capital costs and high operational costs in the beginning. Fintech's role in the payment system, where FinTech is able to replace the role of formal financial institutions such as banks. In the case of payment systems, FinTech has a role in providing markets for businesses, being a tool for payment, settlement / clearing and clearing, 
helping to implement investments more efficiently, mitigating risks from conventional payment systems and helping those who need to save, borrow funds and capital investment.

Financial technology or commonly referred to as fintech, is defined as technological innovation in financial services that can produce business models, applications, processes or products with material effects related to the provision of financial services. Fintech also helps people to more easily get access to financial products and financial literacy. The financial technology industry (fintech) is one of the methods of financial services that is starting to rise in the digital era like today. Digital payments are becoming one of the sectors in the fintech industry that is most developed in Indonesia, so the government and the public hope that digital payments can encourage the number of people who have access to financial services [2]. There are several types of fintech classifications, namely:

\subsubsection{Crowd funding and peer to peer lending}

Crowd funding is a business unit funding technique or business project that involves humans extensively (kemenkeu.go.id, 2017). Peer to peer lending (P2P Lending) is Crowdfunding and Peer to Peer (P2P) Lending is a financial concept that uses information technology assistance to provide easy borrowing and lending money services, where the provider only provides a means that allows lenders and borrowers to lend and borrow by online. This first classification is a marketplace that is a meeting place for capital seekers and investors in the field of loans. With a loan portal that is easily accessible anytime and anywhere, Fintech can reach borrowers and investors throughout Indonesia, for example Kredivo and Pinjam.co [3].

\subsubsection{Market aggregator}

Market aggregator is collecting and managing data that can be used by consumers to help decision making. Market aggregator is a portal that collects and collects financial data to be presented to users. You can compare various financial data to choose the best financial product. For example, when you want to look for KTA products, you can compare several KTA products to see the advantages and disadvantages. For example, CekAja and Pay close attention [3].

\subsubsection{Risk and Investment Management}

Risk and investment management is a financial planner in digital form. In other words, this fintech is to find out your financial condition and to do financial planning easily and quickly. Without the need to contact a financial planner, just open the application on your smartphone and fill in the relevant data to find out the right financial plan according to your needs. For example: jojonomic, Financials, NgaturDuit, and so on [3].

\subsubsection{Payment, settlement and clearing}

Payment, settlement and clearing of the fintech sector with payment system services. This payment portal aims to facilitate and speed up the payment process or transactions via online. Thus, the public in making payments through just one portal via smartphone. Example: OVO, Go Pay, Funds, Tokopedia and so on [3].

\subsubsection{Financial literacy}

Financial literacy is a set of knowledge and skills that enables a person to make effective decisions with all their financial resources. OJK states that the important mission of the financial literacy program is to do so that the Indonesian people can manage finances smartly so that education is needed in the field of finance, so that low knowledge of the financial industry can be overcome and the public is not easily fooled into investment products that offer high returns in the short term without considering the risks. In supporting economic functions, financial literacy is needed because with the large transactions that can be created it will make the wheels of the economy perfect.

Financial literacy has a long-term goal for all classes of society, namely increasing the literacy of someone who was previously less literate or not literate to be well literate and increasing the number of users of financial products and services. In supporting economic functions, financial literacy is needed because with the large transactions, it will make the wheels of the economy perfect [2].

\subsection{Micro, Small and Medium Enterprises (MSMES)}

Based on Law No. 20/2008, the meaning of Micro, Small and Medium Enterprises (UMKM) is:

a. Micro business is productive business owned by individuals and / or individual business entities that meet the criteria for micro business as regulated in this law.

b. Small business is a productive economic business that stands alone, which is carried out by individuals or business entities that are not subsidiaries or non-branch companies that are owned, controlled, or become a part either directly or indirectly from medium or large business enterprises that fulfil small business criteria as referred to in this law.

c. Medium-scale business is a productive economic business that stands alone, which is carried out by individuals or business entities that are not subsidiaries or branches of a company that is owned, controlled, or is part of directly or indirectly with small businesses or large businesses with a number of net assets or annual sales proceeds as stipulated in this law. 
phones and the Internet, Indonesia is a treasure trove. many opportunities fintech untapped. Fintech companies that want to expand in Southeast Asia will be negligent if they ignore Fintech Indonesia's view as a potential market

With the intervention of the regulator and the increasing boom of fintech companies that deal with inclusive financial issues, the World Bank has praised Indonesia as the country in East Asia with the biggest increase in bringing its citizens into the formal financial system in the last three years, especially women.

According to Bank Indonesia data that the long-term trend in Table 1 Indonesia shows a GDP growth per three years where the percentage of GDP in 2013 to 2015 amounted to $5.1 \%$, in 2016 to 2018 amounted to $5.2 \%$, in 2019 to 2021 it was estimated to reach $5.5 \%$ This shows that there is a positive trend in the progress of the Indonesian state which will certainly be followed by the use of technology in its various activities. more than 260 million people, most of whom are under 35 years old and with increasing penetration rates for cellular

Table 1 Indonesian GDP trends quoted from BBVA, Bank Indonesia

\begin{tabular}{|lccc|}
\hline & $\mathbf{2 0 1 3 - 2 0 1 5}$ & $\mathbf{2 0 1 6 - 2 0 1 8}$ & $\mathbf{2 0 1 9 - 2 0 2 1}$ \\
\hline Population (million) & 252 & 262 & 273 \\
GDP (USD bn) & 888 & 1007 & 1296 \\
GDP percapita (USD) & 3525 & 3840 & 4750 \\
GDP Growth (\%) & 5.1 & 5.2 & 5.5 \\
\hline
\end{tabular}

The financial industry in Indonesia is experiencing a shift caused by the birth of a new service format which is a merger between economy and technology (fintech), and produces various solutions that make consumers' lives easier. Lifestyle changes and affordable technology are the main keys to the development of fintech which is very rapid in Indonesia. This also opens up opportunities for banks to offer financial solutions that are more innovative, agile and mobile in accordance with current customer needs. Following the development of Fintech in Indonesia over the past few months.

Table 2 Unit of Accounts Fintech in Indonesia

\begin{tabular}{|c|c|c|c|c|c|c|}
\hline No & Description & $\begin{array}{c}\text { January } \\
2018\end{array}$ & $\begin{array}{l}\text { February } \\
2018\end{array}$ & March 2018 & April 2018 & May 2018 \\
\hline 1 & $\begin{array}{l}\text { Total accumulated lender } \\
\text { accounts (unit of account) }\end{array}$ & 115,939 & 128,119 & 145,965 & 162,373 & 199,539 \\
\hline 2 & $\begin{array}{l}\text { Total accumulated borrower } \\
\text { accounts (unit of account) }\end{array}$ & 330,154 & 546,694 & $1,032,776$ & $1,476,782$ & $1,850,632$ \\
\hline No & Description & June 2018 & July 2018 & August 2018 & $\begin{array}{l}\text { September } \\
2018\end{array}$ & October 2018 \\
\hline 3 & $\begin{array}{l}\text { Total accumulated lender } \\
\text { accounts (unit of account) }\end{array}$ & 123,633 & 135,025 & 150,061 & 161,297 & 182,895 \\
\hline 4 & $\begin{array}{l}\text { Total accumulated borrower } \\
\text { accounts (unit of account) }\end{array}$ & $1,090,306$ & $1,430,357$ & $1,846,273$ & $2,300,007$ & $2,805,026$ \\
\hline No & Description & $\begin{array}{c}\text { November } \\
2018\end{array}$ & $\begin{array}{l}\text { December } \\
2018\end{array}$ & January 2019 & $\begin{array}{c}\text { February } \\
2019\end{array}$ & March 2019 \\
\hline 5 & $\begin{array}{l}\text { Total accumulated lender } \\
\text { accounts (unit of account) }\end{array}$ & 197,729 & 207,507 & $10,663,536$ & $13,788,859$ & $15,667,912$ \\
\hline 6 & $\begin{array}{l}\text { Total accumulated borrower } \\
\text { accounts (unit of account) }\end{array}$ & $3,598,456$ & $4,359,448$ & $17,164,192$ & $19,756,696$ & $22,725,309$ \\
\hline No & Description & April 2019 & May 2019 & June 2019 & July 2019 & August 2019 \\
\hline 7 & $\begin{array}{l}\text { Total accumulated lender } \\
\text { accounts (unit of account) }\end{array}$ & $20,088,120$ & $22,528,584$ & $23,988,288$ & $32,971,425$ & $37,248,541$ \\
\hline 8 & $\begin{array}{l}\text { Total accumulated borrower } \\
\text { accounts (unit of account) }\end{array}$ & $25,689,876$ & $29,305,224$ & $33,119,102$ & $39,804,357$ & $45,715,048$ \\
\hline
\end{tabular}

Table 2 shows an increase in lender and borrowers accounts where in January 2018 the number of lender accounts was 115,939 and in August 2019 there were 37,248,541 shows a very large increase in lenders. meanwhile the borrower account also experienced a significant increase, from January 2018 amounting to 330,154 and the borrower 
year to year shown in the graph below, the orange graph shows the accumulation of borrowers' accounts and the blue graph shows the accumulation of account lenders. account in august 2019 amounting to 45,715,048 the increase was also very significant, this shows that the development of fintech in Indonesia was very high from

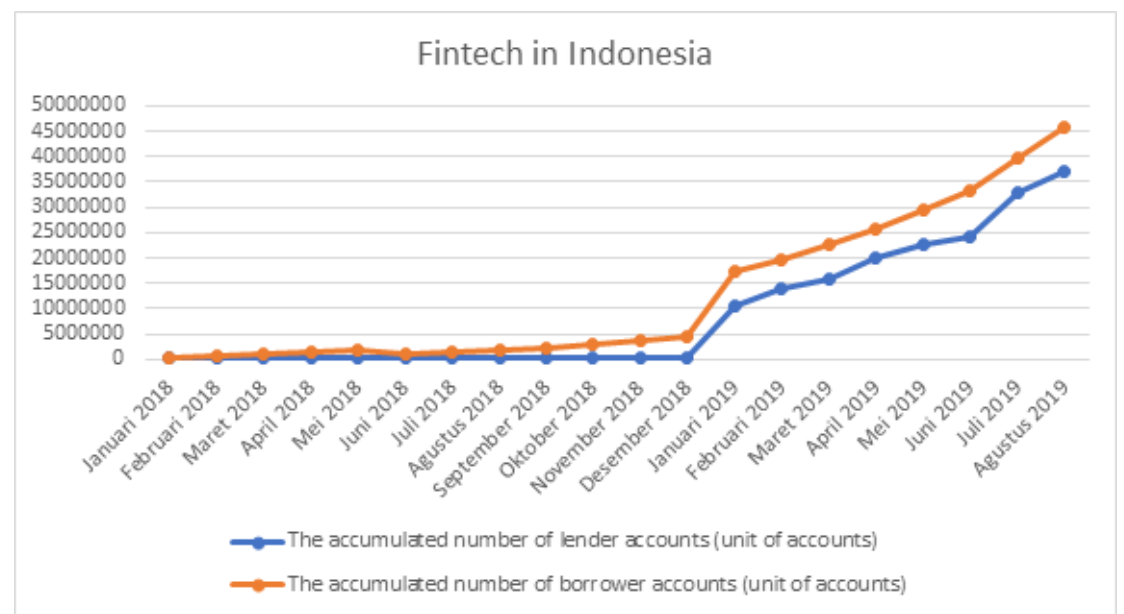

Figure 1 Fintech Accounts in Indonesia

Based on data and graphics showing that fintech in Indonesia has increased significantly from month to month,

this is supported by the increasing number of accounts both lenders and borrowers, the Indonesian people are starting to feel the importance of utilizing fintech in their activities.

Table 3 SMEs Accounts in Indonesia (in Millions)

\begin{tabular}{|c|c|c|c|c|c|c|c|c|c|c|c|}
\hline \multicolumn{12}{|c|}{2018} \\
\hline Jan & Feb & Mar & Apr & May & Jun & Jul & Aug & Sep & Oct & Nov & Dec \\
\hline 14.19 & 14.25 & 14.33 & 14.40 & 14.66 & 14.51 & 14.62 & 14.70 & 14.71 & 14.85 & 14.74 & 14.62 \\
\hline \multicolumn{7}{|c|}{2019} & & & & & \\
\hline Jan & Feb & Mar & Apr & May & Jun & Jul & & & & & \\
\hline 14.66 & 14.82 & 14.91 & 15.04 & 15.27 & 15.37 & 15.54 & & & & & \\
\hline
\end{tabular}

\section{SMEs Accounts in Indonesia}

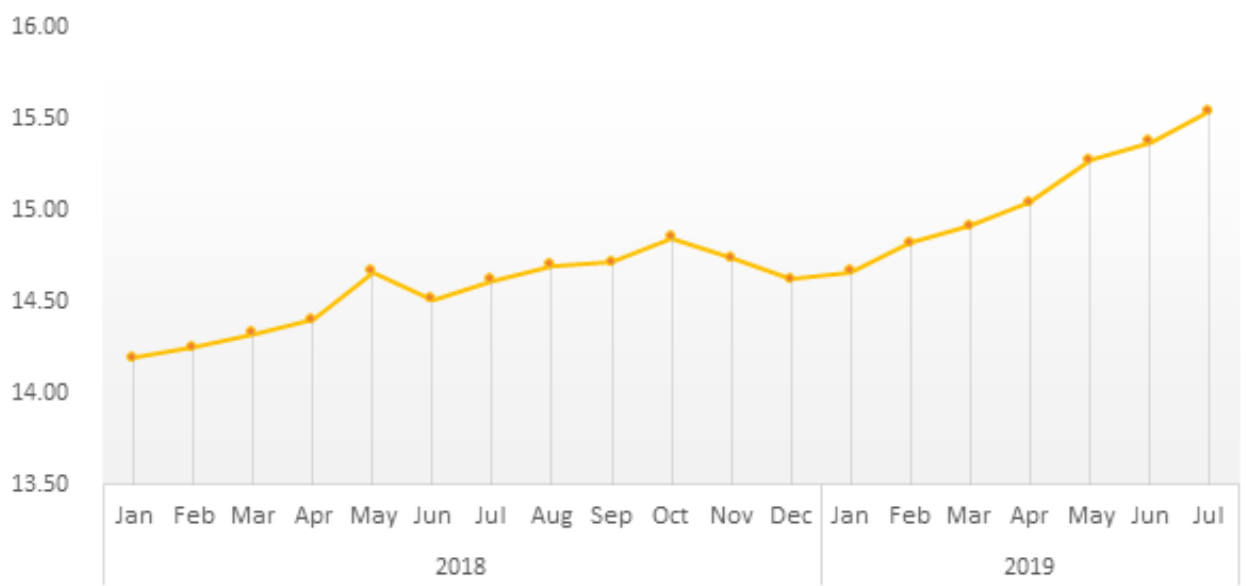

Figure 2 SMEs Accounts in Indonesia (in Millions)

The existence of Fintech for MSMEs in developing their business which in the end, this fintech can increase business capacity. this is shown by the graph of increases in SMEs where in January 2018 SMEs accounts amounted to $14,190,000$ and in July 2019 as many as 15,540,000, so from these data the number of accumulated SMEs accounts increased which impacted on the increase in Gross Domestic Product (GDP) Indonesia. 
Enterprises in Malang. E-JRA Vol. 08 No. August 4, 2019

The development of Fintech is very rapid in Indonesia. Fintech, which has the fastest growth in Indonesia, is a Fintech peer-to-peer loan. The background to the high growth of start-up peer-to-peer lenders in Indonesia is due to the high demand for funds by people who don't have banks. Fintech has an important role in improving the performance of SMEs in increasing its efficiency. Efforts must be made by the government to provide access to SME growth and to provide assistance related to Fintech, complete with good financial inclusion in SME-specific communities, in addition the Government is required to provide licenses aimed at security in the field of fintech so that they can be accessed cheaper, faster, and easier.

\section{REFERENCES}

[1] https://tekno.kompas.com/read/2019/05/16/0326003

7/apjii-jumlah-pengguna-internet-di indonesia-tembus 171-juta-jiwa

[2] Evy Nur Sugiarti, Role of Fintech in Increasing Financial Literacy in Micro, Small and Medium
[3] https://www.finansialku.com/klasifikasi-fintechmenurut-bank-indonesia/ Muhamad Rizal, Fintech As One Of The Financing Solutions For SMEs. Journal of Thought and Research in Business Administration and Entrepreneurship Vol. 3, No. 2, August 2018

[4] Fitri Rusdianasari, The Role of Financial Inclusion through Fintech Integration in Indonesian Financial System Stability. Journal Of Applied Quantitative Economics Vol. 11 No. 2 - August 2018

[5] https://www.bi.go.id/id/edukasi-perlindungankonsumen/edukasi/produk-dan-jasa $\mathrm{sp} /$ fintech/Pages/default.aspx

[6] http://www.ibs.ac.id/img/doc/MDH\%20\%20FinTech\%20IBS\%20June\%202017.pdf

[7] https://fintechnews.sg/20712/indonesia/fintechindonesia-report-2018/ 